\title{
What Type of Defective Feature Do Exceptionally Case-Marked Clauses of Turkish Bear?
}

\author{
Murat Özgen', Özgür Aydın² \\ ${ }^{1}$ Department of Linguistics, Faculty of Letters, Dokuz Eylül University, İzmir, Turkey \\ ${ }^{2}$ Department of Linguistics, Faculty of Language-History and Geography, Ankara University, Ankara, Turkey \\ Email: murat.ozgen@deu.edu.tr, aydino@ankara.edu.tr
}

Received 1 July 2016; accepted 1 August 2016; published 4 August 2016

Copyright (C) 2016 by authors and Scientific Research Publishing Inc.

This work is licensed under the Creative Commons Attribution International License (CC BY). http://creativecommons.org/licenses/by/4.0/

c) (i) Open Access

\begin{abstract}
Core Functional Categories are defined to $b e v^{0}, \mathrm{~T}^{0}, \mathrm{C}^{0}$. They differ in that $\mathrm{T}^{0}$ is not treated as a phase head, while $\mathrm{C}^{0}$ and $v^{0}$ are assumed to be phase heads: 1) a) [+ phase]: $\mathrm{C}^{0}, v\left(^{*}\right)$. b) [- phase]: T0. These heads are assumed to bear uninterpretable $\varphi$-features. $\mathrm{T}^{0}$ forms a defective a domain unless it is selected by $\mathrm{C}^{0}$. In other words, if $\mathrm{T}^{0}$ is selected by the phase head $\mathrm{C}^{0}$, it starts bearing a full $\varphi$-feature set; otherwise, it cannot inherit the features from $\mathrm{C}^{0}$, which leads to a defective domain allowing exceptional case marking (henceforth, ECM). Accordingly, $\mathrm{T}^{0}$ cannot also delete the features of the goal it enters an agree relation. In this respect, the defective features are Case/ $\mathrm{T}^{0}$ features in the sense of Pesetsky \& Torrego (2007). At this point, some other studies suggest that the defectivity is peculiar to only phase heads, and that $\mathrm{T}^{0}$ is ruled out of this argumentation: 2) a) [+ [+/- defective]]: $\mathrm{C}^{0}, v^{0}$. b) [- [+/- defective]]: $\mathrm{T}^{0}$. There is an asymmetry in the understanding of defectivity between these two reasoning. The aim of this study is to discuss this asymmetry, and present evidence as to which distinction on defectivity does exist. We employed ECM data in Turkish to discuss the relevant distinction with reference to specific empirical proofs such as long distance scrambling, binding and negative polarity items. The results of the study support in favor of Pesetsky \& Torrego (2007).
\end{abstract}

\section{Keywords}

Core Functional Categories, Exceptional Case Marking, Defective, Inheritance, Phase

\section{Introduction}

As Chomsky (2001, $2004 \& 2005)$ puts it, $\mathrm{C}^{0}$ and $v^{0}$ are argued to be the phase heads. $\mathrm{T}^{0}$ is not defined as a phase head in his discussions: 
(1) a. [+ phase]: $\mathrm{C}^{0}, v\left(^{*}\right)$

b. [- phase]: $\mathrm{T}^{0}$

All those heads are also defined as Core Functional Categories (henceforth, CFCs). They may bear uninterpretable $\varphi$-features; however, only $\mathrm{C}^{0}$ can be unselected (i.e. be the root). $\mathrm{T}^{0}$ is defective if and only if it is not selected by $C^{0}$ (Chomsky, 2001: p. 102). In other words, $T^{0}$ has a full set of $\varphi$-features if selected by $C^{0}$. The chunk of derivation that has access to a given subarray is called a "phase". Chomsky (2001) asserted that $\mathrm{T}^{0}$ has full $u \varphi$ and EPP features. $\mathrm{T}_{\text {def }}$ means the lack of one of those features. In that case, $\mathrm{T}^{0}$ cannot delete all the features of a goal.

Here, we should shed a light on the term "defectivity". Defective features are $\varphi$-features (see Chomsky 2000; 2001) or Case $/ \mathrm{T}^{0}$ features (see Pesetsky \& Torrego 2007). "Defectivity” means lack of feature (see Chomsky, 2000; 2001) or lack of value (see Pesetsky \& Torrego 2007). Gallego (2007: p. 82) defines a defective category as a "linguistic item which lacks some features of a given class such as number, gender etc.". Following that definition, we may conclude that defective categories such as $\mathrm{T}_{\text {def }}$ or $v_{\text {def }}$ do not mirror phase heads, namely $\mathrm{C}^{0}$ and $v^{0}$. As suggested by Chomsky (2005), $\mathrm{T}^{0}$ cannot inherit any features if it remains unselected by $\mathrm{C}^{0}$, yielding a defective domain, which, in turn, allows for Exceptional Case Marking (henceforth, ECM) constructions:

\section{(2) ECM can be defined as a defective domain.}

As for the defective/non-defective alternation, Chomsky (2000: p. 102) argued that $\mathrm{T}$ comes in two varieties: $\varphi$-complete $\mathrm{T}^{0}$, selected by $\mathrm{C}^{0}$ and $\varphi$-defective $\mathrm{T}^{0}$ selected by $v^{0}$. The former is capable of assigning structural Case, namely nominative, while the latter is incapable of assigning any structural Case. According to Chomsky (2000: p. 124) defectiveness is restricted to $\mathrm{T}^{0}$. On the other hand, in Chomsky (2001), it is argued that $v$ have a defective counterpart: In the case of passive/unaccusative VPs, $v$ is defective, while others are $\varphi$-complete $v$ (i.e. $v^{*}$ ). Richards (2007) follows a similar line with Gallego (2009), and argues that $C^{0}$ and $v^{0}$ have defective/complete counterparts, but $\mathrm{T}^{0}$ has not:

(3) a. $[+[+/-$ defective $]]: \mathrm{C}^{0}, v^{0}$

b. $[-[+/-$ defective $]]: \mathrm{T}^{0}$

Along these lines of thought, the aim of this paper is to question whether it is possible that the phase is defect, even though the phase head is complete, and to seek an answer to the question as to whether all Core Functional Categories (CFCs), namely $v^{0}, \mathrm{~T}^{0}$ and $\mathrm{C}^{0}$, come into defective and complete versions. According to the standard assumption about ECMs as seen in (4a-b), these structures are taken to be introduced by a TP which, due to the lack of the CP layer, is defective (see Chomsky, 2000; 2001 and others).

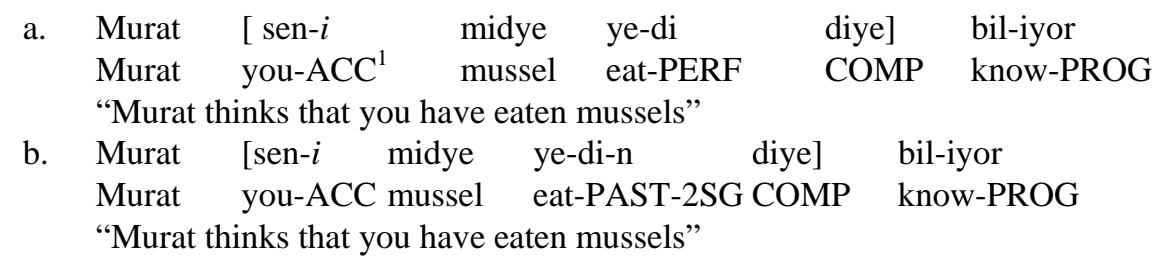

Here, we argue that the analysis in (4) should have a CP layer. We assume that defectivity is not only restricted to $\varphi$-features but it can be also applied to Case or Tense features (see Chomsky, 2000, 2001, 2005 and Pesetsky \& Torrego, 2007). We argue that on the one hand, T is defective in ECM construction in Turkish as in (4b) despite the $\varphi$-complete C; on the other hand, ECM construction in Turkish as in (4a), both $\mathrm{T}^{0}$ and $\mathrm{C}^{0}$ are defective.

\section{ECM}

Rosenbaum (1967) was the first to question whether there is a kind of raising from the subject position of the

\footnotetext{
${ }^{1}$ Throughout the study, we employed the following gloss: acc "accusative”, past "past tense”, comp "complementizer”, prog "progressive”, 2sg "second person singular”, dat "dative”, evid "evidential aspect”, perf "perfective aspect”, prob "probability”, 1sg "first person singular”, loc “locative”, pl "plural”, fut "future”, vnom “verbal nominalizer”, gen "genitive”, pass "passivization”, poss "possesive”, 3sg "third person singular", abl "ablative”, 1pl "first person plural”, neg "negation”.
} 
complement clauses of believe-type verbs to the matrix clauses. His seminal study on the English complement system (Rosenbaum, 1967) started a discussion over this issue, and different analyses have been proposed so far in spite of the fact that the core concern has remained the same. What was meant by raising by Rosenbaum was sentences below:

(5) I believe [him to be an idiot]

Chomsky (1995) stated that the subject of the embedded clause him is within the boundaries of the complement clause in PF while it raises to the Spec, AgrP in LF to check its case feature. Bošković (1997), on the other hand, argues that the subject him raises from the embedded clause to the matrix clause in overt syntax in order to license its case feature via agreement with $v^{0}$.

\subsection{ECM Constructions in Turkish}

\subsubsection{ECM Constructions Are Projections of CP}

Following Şener (2008), we assume that ECM constructions and Finite Complement Clauses are structurally identical: Overt-Finite Complement Clauses are unambiguously CPs being headed by an overt complementizer (i.e., diye), and null-Finite Complement Clauses also project a CP, but the $\mathrm{C}$ head of their $\mathrm{CP}$ is not morphologically realized:

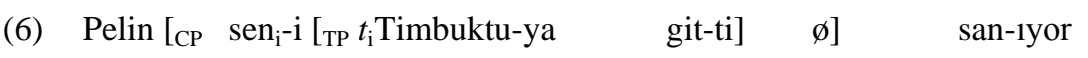
Pelin you-ACC Timbuktu-DAT go-PERF COMP consider-prog

"Pelin considers that you have gone to Timbuktu"

(7) Pelin [CP sen $_{\mathrm{i}}-\mathrm{i}\left[{ }_{\mathrm{TP}} t_{\mathrm{i}}\right.$ Timbuktu-ya git-ti] diye $]$ bil-iyor-muş Pelin you-ACC Timbuktu-DAT go-PERF COMP know-PROG-EVID

"Pelin knows that you have gone to Timbuktu"

\subsubsection{ECM Constructions Are Projections of Defective-T}

As stated before, here we assume that the defectivity is not only limited to $\mathrm{C}^{0}$ head, but it can also be attributed to the Case and Tense features, following Pesetsky \& Torrego (2007). Although the phase head seems to be complete, the phasal domain may still be defective. This argument is borne out by the contrast between (8) and (9) below:

(8) a. Erkin [sen-i İstanbul-a gid-iyor $]$ diye bil-iyor

Erkin you-ACC İstanbul-DAT go-PROG COMP know-PROG

"Erkin knows that you are going to İstanbul"

$\begin{array}{lllll}\text { b. Erkin } \quad \text { sen-i İstanbul-a } & \text { git-ti] diye } & \text { bil-iyor } \\ \text { Erkin you-ACC İstanbul-DAT } & \text { go-PERF COMP } & \text { know-PROG } \\ \text { "Erkin knows that you have gone to İ́stanbul" } & & \end{array}$

$\begin{array}{lllll}\text { c. } & \text { Erkin } & \text { [sen-i İstanbul-a } & \text { gid-ecek] diye } & \text { bil-iyor } \\ \text { Erkin } & \text { you-ACC İstanbul-DAT } & \text { go-PROB COMP } & \text { know-PROG }\end{array}$

"Erkin knows that you will go to İstanbul"

(9) a. *Erkin [sen-i İstanbul-a gid-iyor-du] diye bil-iyor

Erkin you-ACC İstanbul-DAT go-PROG-PAST COMP know-PROG

"(intended) Erkin knows that you were going to İstanbul"

b. *Erkin [sen-i İstanbul-a git-ti-ydi/git-miş-ti] Erkin you-ACC İstanbul-DAT go-PERF-PAST/go-EVID-PAST COMP know-PROG

"(intended) Erkin knows that you had gone to İstanbul"

c. *Erkin [sen-i İstanbul-a gid-ecek-ti] diye bil-iyor Erkin you-ACC İstanbul-DAT go-PROB-PAST COMP know-PROG "(intended) Erkin knows that you would go to İstanbul"

According to Erguvanl1-Taylan (1996), if there are these following morphemes without any other tense or 
modality marker along with them $(\{-(I) y o r\},\{-D I\}$ and $\{-(y) A c A k\})$, then they are more likely to be ambiguous in their functions. For instance, $\{-D I\}$ morpheme in the examples (10) in fact has hardly any past tense reading as reflected by the English translations:

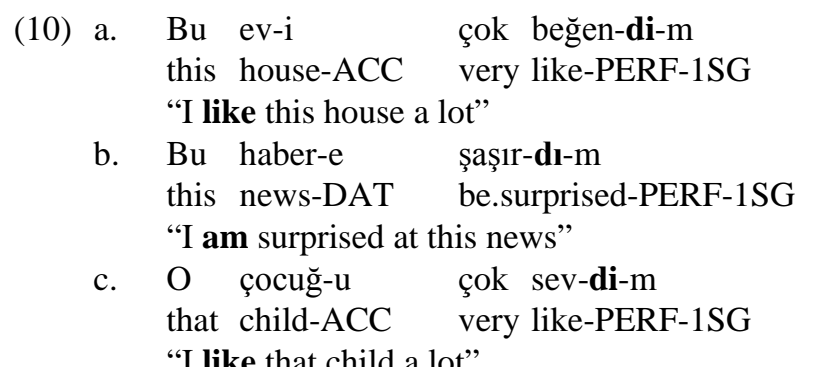

Yavaş (1980: pp. 129-130)

Erguvanl1-Taylan (1996) argued that $\{-D I\}$ typically referred to as the past tense marker is also the marker of perfective viewpoint. Thus, $\{-D I\}$ is not genuine tense marker, but $\{-(y) D I\}$ is. $\{-(I) y o r\}$ usually referred to as the present tense is the imperfective viewpoint marker. Furthermore, $\{-(y) A c A k\}$ is the future modal usually stating possibility. By this way, Uzun (1998) argued that $\{-(I) y o r\},\{-D I\}$ and $\{-(y) A c A k\}$ are not tense markers. According to him, the tense markers in Turkish are $\{-(y) D I\}$ for past and $\{-\varnothing\}$ for present (i.e., non-past).

Returning to the examples given in (8) and (9), we see that in (8a-c) there are no tense markers on the verb conjugation; therefore, we may state that $\mathrm{T}^{0} \mathrm{~s}$ in $(8 \mathrm{a}-\mathrm{c})$ are defective, thus, the ECM structure. What is seen in examples $(9 \mathrm{a}-\mathrm{c})$ is that there is a tense marker on the verb conjugation which means that $\mathrm{Ts}$ in these examples are not defective. Note that the phase heads in (8) and (9) are defective as can be seen from the zero person agreement between the ECM-subject and the verb. The reason why the contrast between these two example-sets is significant is that in (9) ECM is not allowed even though the phase head (i.e. $\mathrm{C}^{0}$ ) is not complete lacking $\phi$-features. This implies the fact that there might be some other motivations other than the phase head itself driving the phasal area to be either a full or defective area. We can see a similar effect when a clause with a nominal predicate (i.e. a predicate which allows only tense marking but modal or aspectual marking) is inserted:

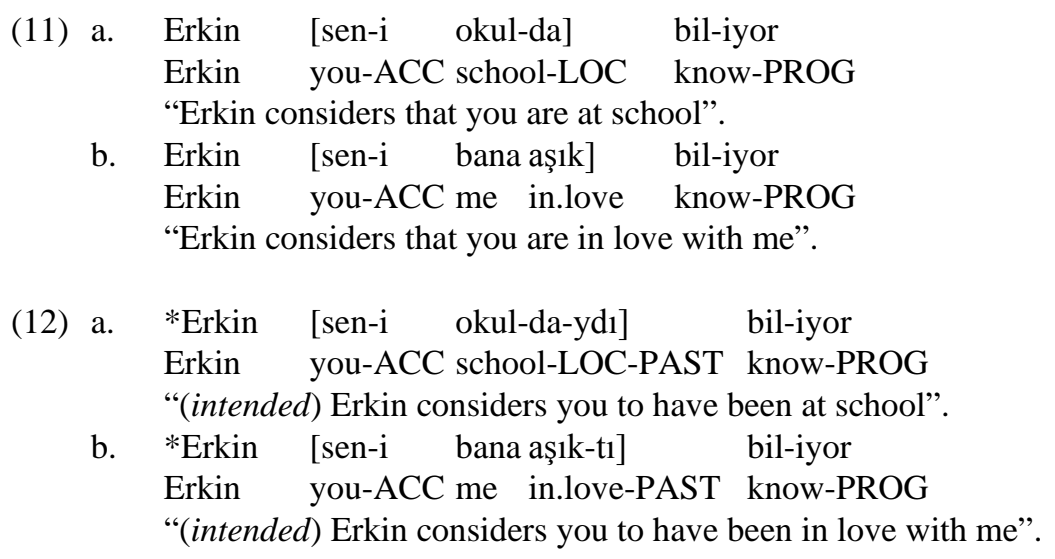

Examples given in $(11$ - 12) clearly show that ECM-clauses with tense marking yield ungrammaticality. It implies that tense might be one of the key factors that determine the opacity of such clauses. However, one needs further argumentation as to the ungrammaticality of these domains. The pair given below in (13) bears an asymmetry:

(13) a. $\begin{aligned} & \text { Ben [Ali dün } \\ & \text { bil-iyor-um }\end{aligned}$
I Ali yesterday that hour-PL-LOC office-LOC
know-PROG-1SG


"Ali knows that you were working at the office at that time yesterday".

b. *Ben [Ali dün o saat-ler-de büro-da çalış-lyor] diye] bil-iyor-um

I Ali yesterday that hour-PL-LOC office-LOC work-PROG COMP know-PROG-1SG

"(intended) Ali knows that you were working at the office at that time yesterday".

In (13a), we see a full-finite subordinate clause in brackets. We can also see a complementizer diye. All these factors show that (13a) bears a full-finite subordinate clause. That is the basic reason why the time adverbial dün "yesterday" can appear within the boundaries of this subordinate clause since it has been licensed by the past tense marker $\{-(y) D I\}$ on the verb. Now, let us see what we have in an ECM-clause:

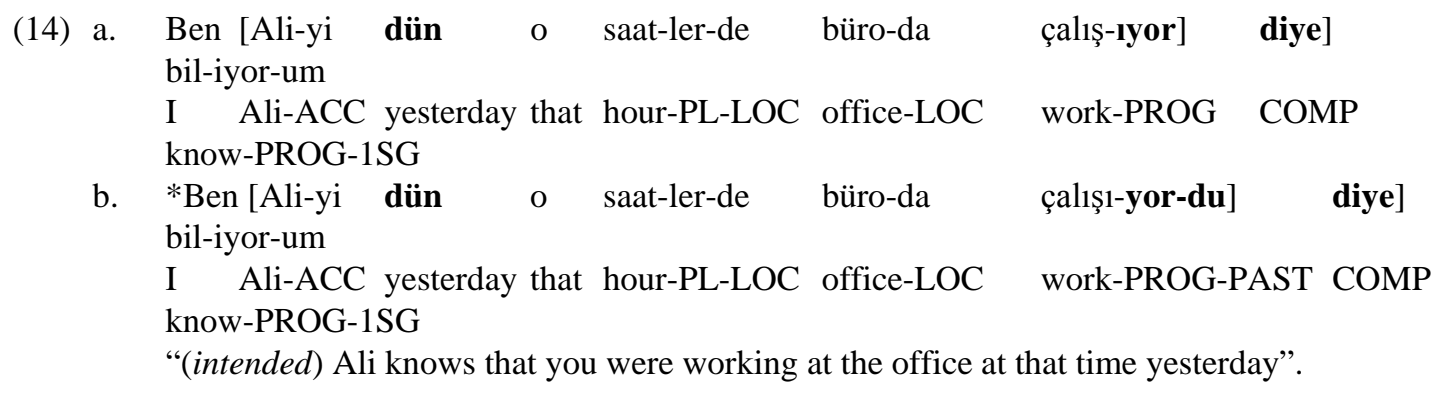

(14a) behaves like a defective clause with an accusative marked subject Ali-yi. However, it behaves like a CP as it bears a complementizer diye. The asymmetry between the grammaticalities of (14a) and (14b) stems from the fact that in (14b) past tense marker $\{-(y) D I\}$ has been realized on the verb of the embedded clause. This might seem strange since (13a) is grammatical only with a past tense marker. For this reason, the asymmetry between pairs in (13a-b) and (14a-b) strongly implies that ECM-clauses in Turkish seem to lack tense feature. However, we need further arguments to speak in favor of this preliminary observation.

\subsection{Complete- $\mathrm{C}^{0}$ Defective- $\mathrm{T}^{0}$ in ECM Constructions}

Let us repeat the introductory examples we have given in the beginning of this study. The gloss can be copied from the examples given above:

$(1 \forall)$ a. Murat [sen-i midye ye-di] diye bil-iyor. A-type

b. Murat [sen-i midye ye-di-n] diye bil-iyor B-type

Following Şener (2008), let us mark these two different ECM-structures as A-type and B-type respectively. Knecht (1985) reported that only (1b) is acceptable in Turkish, while it was reported in Pullum (1975) that (1b) is not possible but (1a) is. Kornfilt (1977) makes the empirical claim that (1b) and (1a) are not part of the same dialect, and accordingly (1b) and (1a) belong to speakers of different dialects. Aygen (2002), Kural (1993), Zidani-Eroğlu (1997) claim that both (1b) and (1a) exist in Turkish (i.e., agreement is optional). He disagreed with the claim that there is a dialectal difference among speakers with respect to their judgments regarding (1b) and (1a) as the variation exists among speakers of Istanbul Turkish, the standard dialect, and side with the latter group of researchers in the relevant respect. Besides, he also maintained that it is true that speakers generally pick one over the other (possibly an instance of idiolectal variation). We completely agree with this idea since neither of the native speakers we have consulted rejects either of them completely. What is crucial here is that like (1a), (1b) has also defective $\mathrm{T}^{0}$ :

$\begin{array}{lllll}\text { (15) a. } & \text { Erkin } & \text { [sen-i İstanbul-a } & \text { gid-iyor-sun] } & \text { bil-iyor } \\ & \text { Erkin } & \text { you-ACC İstanbul-DAT } & \text { go-PROG-2SG } & \text { know-PROG }\end{array}$ "Erkin supposes that you are going to İstanbul"

b. Erkin [sen-i İstanbul-a git-ti-n/git-miş-sin] bil-iyor 
Erkin you-ACC İstanbul-DAT go-PERF-2SG/go-EVID-2SG know-PROG

"Erkin supposes that you have gone to İstanbul"

$\begin{array}{lllll}\text { c. Erkin } \quad \text { [sen-i İstanbul-a } & \text { gid-ecek-sin] } & \text { bil-iyor } \\ \text { Erkin you-ACC İstanbul-DAT go-FUT-2SG } & \text { know-PROG } \\ & \text { "Erkin supposes that you will go to İstanbul" }\end{array}$

Similar to the example given in (14a), (15a-b-c) seem to lack tense feature. This prediction is borne out by the ungrammaticalities of (16a-b-c):

(16) a. *Erkin [sen-i İstanbul-a gid-iyor-du-n] bil-iyor

Erkin you-ACC İstanbul-DAT go-PROG-PAST-2SG know-PROG

"(intended) Erkin supposes that you were going to İstanbul".

b. *Erkin [sen-i İstanbul-a git-ti-ydi-n/git-miş-ti-n] bil-iyor

Erkin you-ACC İstanbul-DAT go-PERF-PAST-2SG/go-EVID-PAST-2SG know-PROG

"(intended) Erkin supposes that you had gone to İstanbul".

c. *Erkin [sen-i İstanbul-a gid-ecek-ti-n] bil-iyor

Erkin you-ACC İstanbul-DAT go-PROB-PAST-2SG know-PROG

"(intended) Erkin supposes that you would go to İstanbul".

As the examples presented in (16a-b-c) bear agreement marking on the verbs of their subordinate clauses, it should mean that they bear a complete $\mathrm{C}^{0}$ head. The fact that they yield ungrammaticality when tense morpheme is realized reveals that those B-type ECM clauses has defective $\mathrm{T}^{0}$ s but a complete $\mathrm{C}^{0}$ head, in contrast to A-type ECM clauses, which lack both of them.

\section{Non-Phase with Complete $\mathrm{C}^{0}$}

The examples of A-type and B-type ECM clauses discussed above suggest that those domains lack either tense or agreement features. Following Chomsky (2008), we assume that these domains should be rendered as defective domains and should not count as a phase as $\mathrm{C}^{0}$ lacks one or both of the features (i.e. tense or agreement). However, one needs further evidence to prove this preliminary conceptual argument.

\subsection{Evidence 1: Long-Distance Scrambling}

Assuming that long-distance scrambling is A'-movement (Dayal, 1994; Müller \& Sternefeld, 1994; Vikner, 1994; Miyagawa, 1997 among others), it should allow reconstruction. Therefore, it is impossible to reconstruct to a domain which has already been spelled-out to interfaces. Here, one can evidence for a non-phase CP. To say, long-distance scrambling occurs in two types ECM (and Finite Complement Clauses) but not in root clauses:

(17) A-type ECM clause
a. Ali [sen-i İstanbul-a git-ti] san-1yor
Ali you-ACC İstanbul-DAT go-PERF consider-PROG
b. Ali [sen-i $t_{\mathrm{i}}$ git-ti] san-1yor İstanbul- $\mathrm{a}_{\mathrm{i}}$
c. Ali $\left[t_{\mathrm{i}}\right.$ İstanbul-a git-ti] san-1yor sen- $\mathrm{i}_{\mathrm{i}}$
"Ali considers you to have gone to İstanbul".

First, we see an A-type ECM clause, which supposedly lacks tense feature and obviously an agreement marker. (17) reveals that the bracketed clause is a non-phase CP domain since the constituents in (17b-c) are allowed to reconstruct after a long-distance scrambling operation. B-type ECM clauses also yield grammaticality when an element is scrambled out of its clause to the matrix clause domain:

(18) B-type ECM clause
a. Ali [sen-i İstanbul-a git-ti-n] san-1yor
Ali you-ACC İstanbul-DAT go-PERF-2SG consider-PROG
b. Ali [sen-i $t_{\mathrm{i}}$ git-ti-n] san-1yor İstanbul- $\mathrm{a}_{\mathrm{i}}$
c. Ali $\left[t_{\mathrm{i}}\right.$ İstanbul-a git-ti-n $]$ san-1yor sen- $\mathrm{i}_{\mathrm{i}}$ 
“Ali considers you to have gone to İstanbul”.

Different from A-type ECM clauses, B-type ECM clauses must be lacking tense features due to the fact that this ECM domain allows long distance scrambling. One can see the agreement marking on the embedded verb; however, scrambling of the constituents in (18b-c) suggests that this domain is a non-phase CP domain owing to a missing feature, i.e. tense. We can obtain the same effect with finite complement clauses:

(19) Finite Complement Clauses
a. Ali [sen-in İstanbul-
git-tiğ-in]-i
san-1yor
Ali you-GEN İstanbul-DAT go-VNOM-poss.2SG-ACC
b. Ali $\left[\right.$ sen-in $t_{1}$
git-tiğ-in]-1
san-1yor İstanbul-a $\mathrm{a}_{\mathrm{i}}$
c. Ali $\left[t_{\mathrm{i}} \quad\right.$ İstanbul-a git-tiğ-in]-i san-1yor sen-in ${ }_{\mathrm{i}}$
"Ali is considering the fact that you have gone to İstanbul".

Given that no tense or aspectual marking has been encoded on the embedded verb, we can readily observe and state that these noun clauses are marked with genitive-possessive constructions and that they certainly lack tense features:
(20) a.
Ali dün [sen-in İstanbul-a git-tĭğ-in]-i
Ali yesterday you-GEN İstanbul-DAT go-VNOM-POSS.2SG-ACC "Yesterday, Ali considered that you had gone to İstanbul".
b. Ali yarın [sen-in İstanbul-a git-tiğ-in]-i "Tomorrow, Ali will consider that you have gone to İstanbul".
Ali tomorrow you-GEN İstanbul-DAT go-VNOM-POSS.2SG-ACC consider-PROB

\author{
san-1yor-du \\ consider-PROG-PAST \\ san-acak
}

The adverb dün "yesterday" and the past tense marking on the matrix verb in (20a) as well as the adverb yartn "tomorrow" with a future marking on the matrix verb in (20b) bear out the idea that the bracketed nominal clauses do lack tense features. If they did not lack, then, the following bracketed root clause would be rendered grammatical since the root clause given in (21) truly contains a tense marking:
(21) *Ali yarın [sen İstanbul-a
gid-iyor-du-n]
san-acak
Al tomorrow you İstanbul-DAT go-PROG-PAST-2SG
consider-PROB

Seeing that (21) is ungrammatical confirms the idea that the nominal clauses in (20a-b) lack tense features. Therefore, we can argue that the clauses in (17 - 18) is similar to (19) in that (19) lacks tense features as well since long-distance scrambling test yield the same results. (22) includes root clauses:

(22) Root clauses
a. Ali [sen İstanbul-a gid-iyor-du-n]
Ali you İstanbul-DAT go-PROG-PAST-2SG
san-mış
b* Ali [sen $t_{\mathrm{i}}$
gid-iyor-du-n] san-mış İstanbul-a $\mathrm{a}_{\mathrm{i}}$
c. *Ali $\left[t_{\mathrm{i}}\right.$ İstanbul-a gid-iyor-du-n] $\operatorname{san-mış~}$ sen $_{\mathrm{i}}$

The fact that the embedded clauses in (22) include tense and agreement marking shows that they are phasal $\mathrm{CP}$ domains. This observation is borne out by the fact that long-distance scrambling is not allowed in (22b-c), which suggests that there is no reconstruction point after the constituents have been moved since the bracketed clauses will be spelt-out. We can readily conclude that only root clauses constitute phasal domains, whereas the other types (i.e. A-type and B-type) cannot. These points reveal that tense is a determining factor of phase hood. In other words, complete $\mathrm{C}^{0}$ with all agreement features cannot be a sole determining factor of phase hood.

\subsection{Evidence 2: Binding}

The fact that A-type ECM clauses and B-type ECM clauses can be a defective domain has been discussed with empirical evidence of long-distance scrambling. Another evidence that these domains are defective domains 
comes from binding data. As Phase Impenetrability Condition (Chomsky, 2005) stipulates, no other syntactic operation can be carried out on a spelt-out domain, since that domain has already been transferred to interfaces, i.e. <phon, sem>. Therefore, binding conditions are formed along these lines by Lee-Schoenfeld (2004: p. 147):

\section{(23) Principle A}

An anaphor should be bound in its accessible phase.

What we understand from this formulation of Principle A is that an anaphor cannot be bound by an antecedent in a different spell-out domain. Therefore, we can employ this reasoning to test whether this also applies to A-type and B-type ECM clauses or not. We observe that anaphors can be bound by the main subject in two types ECM (and Finite Complement Clauses) but not in root clauses:

(24) A-type ECM clause
a. $\quad$ Biz $_{\mathrm{i}}$ [birbir-imiz- $\mathrm{i}_{\mathrm{i}}$ we each.other-1PL.POSS-ACC theatre-DAT go-PERF consider-PROG-PAST-1PL "We were considering each other to have gone to the theatre".
b. $\quad$ Ali $_{\mathrm{i}}$ [biz-i kendi-n-den $\mathrm{i}_{\mathrm{i}}$ kork-uyor] san-1yor Ali we-ACC self-3SG-ABL frighten-PROG consider-PROG
"Ali considers us to be afraid of him"

A-type ECM clauses lack tense and agreement feature; thus, they are deemed to be non-phasal domains. A-type ECM clauses seem to be truly non-phasal domains since a reciprocal pronoun birbirimizi can be bound by an external antecedent as shown in (24a). Similarly, a reflexive pronoun kendinden can also be bound with an external antecedent as shown in (25b). Following Lee-Schoenfeld's (2004: p. 147) formulation, we can say that binding data also supports the idea that A-type ECM clausal domains are defective. Now, let us see whether this test will yield the same result from B-type ECM clauses:

\section{(25) B-type ECM clauses}
a. Biz $_{\mathrm{i}}\left[\right.$ birbir-imiz- $\mathrm{i}_{\mathrm{i}}$
tiyatro-ya git-ti-k] san-1yor-du-k
we each.other-1PL.POSS-ACC theatre-DAT go-PERF-1PL consider-PROG-PAST-1PL
"We were considering each other to have gone to the theatre".
b. Ali $_{i}$ [biz-i kendi-n-den ${ }_{i}$ kork-uyor-uz] san-1yor
Ali we-ACC self-3SG-ABL frighten-PROG-1PL consider-PROG
"Ali considers us to be afraid of him"

Similar to A-type ECM clauses, B-type ECM clauses yield the same effect as to whether anaphors can be bound to an external antecedent. The reciprocal pronoun birbirimizi can be bound by an external antecedent as shown in (25a), and the reflexive pronoun kendinden can also be bound with an external antecedent as shown in (25b). Here, we are again able to conclude that B-type ECM clausal domains are also defective domains. The same effect can be observed in finite complement clauses, which certainly lack tense feature as previously discussed in (20):

(26) Finite Complement Clauses
a. $\quad$ Biz $_{\mathrm{i}}\left[\right.$ birbir-imiz-in ${ }_{\mathrm{i}}$
san-1yor-du-k
we each.other-1PL.POSS-GEN theatre-DAT go-VNOM-3SG.POSS-ACC consider-PROG-PAST-1PL
"We were considering each other to have gone to the theatre".
b. Ali $i_{i}$ [biz-im kendi-n-den ${ }_{i}$ kork-tuğ-umuz]-u san-ıyor
Ali we-GEN self-3SG-ABL frighten-VNOM-1PL.POSS-ACC consider-PROG
"Ali considers us to be afraid of him"

In the clauses given in (26), we can observe that the reflexive pronoun kendinden and the reciprocal pronoun 
birbirimizin have been bound by external arguments respectively, biz and Ali. As remembered, in A-type and B-type ECM clauses, the domains were defective. Observing this effect in finite complement clauses as well suggests that A-type and B-type ECM clauses must be lacking tense features in order to be defective, since we already know that finite complement clauses lack tense features. Last, we can expect that root clauses should behave differently than A-type and B-type ECM clauses due to the fact that root clauses bear tense and agreement marking and assumed to be full CP domains; thus, a phasal domain:

(27) Root clauses

a. $\quad * \mathrm{Biz}_{\mathrm{i}}\left[\right.$ birbir-imiz $\mathrm{z}_{\mathrm{i}} \quad$ tiyatro-ya git-iyor-du-k] san-1yor-du-k we each.other-1PL.POSS theatre-DAT go-PROG-PAST-1PL consider-PROG-PAST-1PL "(literal) *We were considering that each other was going to the theatre".

b. * Ali $_{\mathrm{i}}\left[\right.$ biz kendi-n-den $\mathrm{i}_{\mathrm{i}}$ kork-uyor-du-k] san-1yor Ali we self-3SG-ABL frighten-PROG-PAST-1PL consider-PROG "(literal) *Ali considers that we were afraid of himself"

The embedded root clauses bear tense and agreement marking, which shows that these domains are full CP phasal domains. It is borne out by the fact that binding of anaphors by an external antecedent in (27a-b) is not permitted, unlike (24), (25) and (26). This is certainly because this domain is a phasal domain; therefore, the anaphors are spelt out before they are bound by the external antecedents. On the basis of the binding data presented here, we can here reach the conclusion that only root clauses constitute phasal domains, which reveals that complete $\mathrm{C}^{0}$ with all agreement features cannot be a sole determining factor of phase hood. Following these two strong arguments as to the determining factor of phase hood, we can now discuss the third strong empirical argument in this sense; that is, negative polarity items.

\subsection{Evidence 3: Negative Polarity Items}

Negative polarity items (henceforth, NPIs) are expressions that need to occur within negative contexts or be licensed by an overt marker of negation. They usually appear within negative clauses, and some can appear within affirmative questions as well (Göksel \& Kerslake, 2005). Negative polarity items in Turkish are categorized into three groups by Kelepir (2001) based on their morphological features:

1) The adverb hiç—-at all" "never" "ever".

2) The words which begin with hiç-hiç kimse "anybody/nobody", hiçbirşey "anything/nothing”, hiçbir X "any $\mathrm{X} / \mathrm{no} \mathrm{X}$ ”.

3) The words without hiç-kimse "anybody/nobody", asla "never” "ever", sakın "ever”, katiyyen "in any way".

Herburger (2001: p. 292) proposes a distinction between negative items (henceforth, NIs) and negative polarity items. The basic difference between NPIs and NIs is that NIs are truly negative and they do not require any other clause mate negation marking unlike NPIs. Therefore, negative statements like those exemplified below in (1a) and (1b) can only be constructed by NPIs (Kelepir, 2001).

(28) a. Ali kimse-yi gör-me-di.

Ali anybody-ACC see-NEG-PAST

"Ali didn't see anybody"

b. *Ali kimse-yi gör-dü.

Ali anybody-ACC see-PAST-3SG

"(literal) *Ali saw anybody"

NPIs, in this respect, can be counted as another evidence for non-phase CP. As has already been stated, NPIs in Turkish can be licensed by negation marking. As shown in A-type, B type and (and Finite Complement Clauses), NPIs can be licensed by the embedded or matrix negation. However, this is not the case in finite clauses (root clauses). The negation marker that has raised to the main clause cannot license the NPI inside the embedded clause:

(29) A-type ECM clauses 

a. Polis [sen-i kimse-ye vur-du] bil-mi-yor
police you-ACC anybody-ACC hit-PERF suppose-NEG-PROG
"(intended) The police suppose that you hit nobody"
b. Polis [sen-i kimse-ye vur-ma-d1] bil-iyor
police you-ACC anybody-ACC hit-NEG-PERF suppose-PROG

"The police suppose that you hit nobody"

In (29a), we see an A-type ECM clause. The bracketed clause lacks an overt complementizer and supposedly a tense marking. The negation morpheme $\{-m A\}$ is attached to the matrix verb, but the NPI kimseye stands within the bracketed clause. The grammaticality of (29b) is expected since the negation marking and the NPI occur within the same domain. However, the grammaticality of (29a) is unexpected due to the fact that negation marking and the NPI are in different spell-out domains. The NPI test employed here suggests that A-type ECM clauses are non-phasal domains. Moving our attention from A-type ECM clauses to B-type ECM clauses, we observe the same effect in the mentioned clause type:

(30) B-type ECM clauses
a. Polis [sen-i kimse-ye vur-du-n] bil-mi-yor police you-ACC anybody-ACC hit-PERF-2SG suppose-NEG-PROG "(intended) The police suppose that you hit nobody"
b. Polis [sen-i kimse-ye vur-ma-dı-n] bil-iyor police you-ACC anybody-ACC hit-NEG-PERF-2SG suppose-PROG
"The police suppose that you hit nobody"

In a similar fashion, (29b) is grammatical, which is expected since the negation marking and the NPI kimseye occur within the same spell-out domain (if there is any). On the contrary, the grammaticality of (29a) is unexpected due to the same reason discussed above. This time, the mentioned clause bears an agreement marking (i.e. [2sg] “- $n$ ”) as well. However, the NPI has somehow been licensed and (29b) is rendered as grammatical. The NPI test here reveals that B-type ECM clauses include also non-phasal domains as did A-type ECM clauses. These observations are borne out by the following examples including finite complement clauses:

(31) Finite complement clauses
a. Polis [sen-in kimse-ye vur-duğ-un]-u
police you-GEN anybody-DAT hit-VNOM-2SG.POSS-ACC
"The police suppose you to have hit nobody"
b. Polis [sen-in kimse-ye vur-ma-dı̆-
police you-GEN anybody-DAT hit-NEG-VNOM-2SG.POSS-ACC suppose-PROG
"The police suppose you to have hit nobody"

Since finite complement clauses lack an overt complementizer as well as tense marking, they are transparent domains in that such clauses are considered to be non-phasal domains. Thus, one may expect that NPIs can be licensed either clause-internally or clause-externally. This is indeed what we have observed in (31a-b). In (31a), the licensing of the NPI is distant, whereas in (31b) it is local. This similarity between A-type and B-type ECM clauses, and finite complement clauses proves the claim that A-type and B-type ECM clauses are non-phasal domains.

Last, we turn our attention to root clauses to see whether we will observe the same effect in such clauses. We already know that root clauses are opaque domains since they are phases:

(32) Root clauses
a. *Polis [sen kimse-ye vur-uyor-du-n] bil-mi-yor police you anybody-DAT hit-PROG-PAST-2SG suppose-NEG-PROG
"(literal) *The police don't suppose that you were hitting anybody"
b. Polis [sen kimse-ye vur-mu-yor-du-n] bil-iyor police you anybody-DAT hit-NEG-PROG-PAST-2SG suppose-PROG


“The police suppose that you weren’t hitting anybody”.

We see that (32a) is ungrammatical since root clauses are deemed to be full CPs, thus phases. Therefore, root clauses behave differently in this respect. Unlike the clauses given in (30) and (31), the licensing in (32) cannot be distant, for c-commanding is not allowed. It is due to the fact in (32a) the bracketed clause has been spelt out before the NPI is licensed. On the basis of the data discussed above, we can reach the conclusion that full $\mathrm{T}^{0}$ as well as full $\mathrm{C}^{0}$ is a determining factor as to the phase hood of a domain ${ }^{2}$. Now, we move on to discuss how such constructions are derived, and draw the main framework which leads us to the determining factor of phase hood. Therefore, we can have the chance to see what is missing in ECM clauses.

\section{What Is Missing in ECM Clauses of Turkish?}

Along the lines of the empirical evidence argued above, we can easily observe that the structuring of A-type and B-type ECM clauses differ from that of root clauses in that the former resembles to finite complement clauses. As has been stated previously, finite complement clauses obviously lack tense marking; thus, stand as a nonphasal domain. In this respect, A-type and B-type ECM clauses, and finite complement clauses can be deemed as transparent domains as illustrated below (33), (34) and (35):

(33) A-type ECM clauses

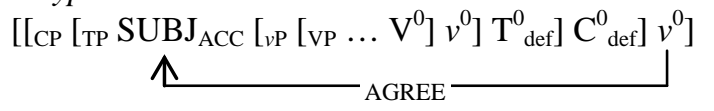

(34) B-type ECM clause

$$
\left.\left[{ }_{\mathrm{CP}}\left[\mathrm{TP}_{\mathrm{TP}} \mathrm{SUBJ}_{\mathrm{ACC}}\left[{ }_{\mathrm{vP}}\left[\mathrm{vP} \ldots \mathrm{V}^{0}\right] v^{0}\right] \mathrm{T}_{\text {def }}^{0}\right] \mathrm{C}_{\text {comp }}^{0}\right] v^{0}\right]
$$

(35) Finite complement clauses

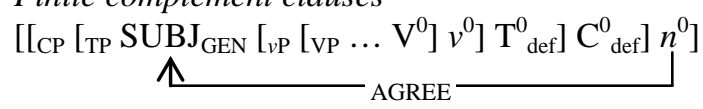

(33) includes an A-type ECM clause in which $\mathrm{T}^{0}$ and $\mathrm{C}^{0}$ are defective. Therefore, $v^{0}$ of the matrix clause can license the subject the embedded clause. Therefore, we see accusative marking on the subject of the embedded clause. However, no tense or agreement is seen on the verb of the embedded clause since $\mathrm{T}^{0}$ and $\mathrm{C}^{0}$ are defective. (34) resembles to (33) no tense marking is displayed since $\mathrm{T}^{0}$ is defective. However, in B-type ECM clauses, we can observe agreement since $\mathrm{C}^{0}$ is not defective. Even if this is the case, we still see an ECM clause whose subject is licensed by the matrix clause. On the other hand, we have root clauses, the structuring of which is totally different from that of A-type and B-type ECM clauses:

(36) Root clauses

$$
\left.\left[{ }_{\mathrm{CP}}\left[\mathrm{TP} \mathrm{SUBJ}_{\mathrm{NOM}}[\underbrace{}_{\mathrm{vp}}\left[\mathrm{vP} \ldots \mathrm{V}^{0}\right] v^{0}] \mathrm{T}^{0}{ }_{\text {comp }}\right] \mathrm{C}_{\text {comp }}^{0}\right] v^{0}\right]
$$

${ }^{2}$ These observations can also be tested on the basis of small clauses. Since small clauses need further argumentation, we are not taking them into the main analysis. However, we can observe the same effect in both types of clauses:

1) A-type ECM clause
a. Ben [sen-I
kimse-ye borçlu]
san-m1-yor-du-m
I you-acc anybody-dat indebted
b. Ben [sen-i
kimse-ye borçlu]
suppose-neg-prog-past-1sg
değil san-1yor-du-m
I you-acc anybody-dat indebted
"I suppose you to be indebted to nobody"
2) B-type ECM clause
a. Ben [sen-i
I you-acc
b. Ben [sen-I
kimse-ye borçlu-sun] san-mı-yor-du-m
anybody-dat indebted-2sgsuppose-neg-prog-past-1sg
I you-acc anybody-dat indebted
"I suppose you to be indebted to nobody"

$$
\begin{array}{ll}
\text { değil-sin] } & \text { san-1yor-du-m } \\
\text { neg-2sg } & \text { suppose-prog-past-1sg }
\end{array}
$$


Root clauses have full $\mathrm{T}^{0}$ as well as full $\mathrm{C}^{0}$. In other words, we can observe tense marking and agreement on the verb of the embedded clause. Therefore, root clauses can stand as a phasal domain, and the shaded area in (36) stands for the spell-out domain. As a natural consequence of this spell-out mechanism, the matrix $v^{0}$ cannot see the subject of the embedded clause; therefore, it cannot interfere with it. As this domain bears full tense and agreement features, the subject agrees with embedded $\mathrm{T}^{0}$, but not with matrix $v^{0}$.

So far, we have seen how accusative marking is or is not marked on the subject of the embedded clause. The real question here deserves a closer inspection, and the question here is what makes it possible for the derivation to mark the subject of the embedded clause with accusative case. In order to answer this question, we should focus on B-type and root clauses repeated here in (37a-b):

\section{(37) a. B-type ECM clause}

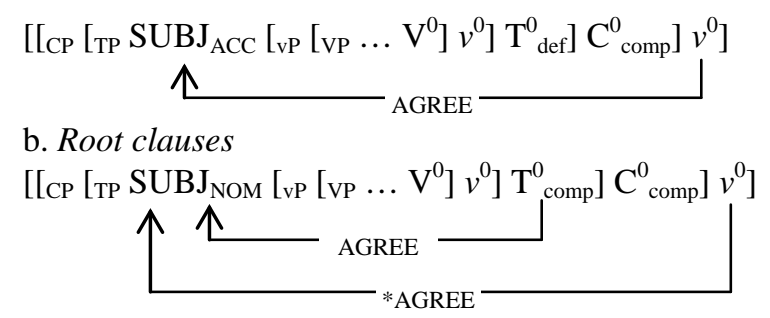

Since A-type ECM clauses have no agreement marking; thus a defective $\mathrm{C}^{0}$, we leave it out of the inspection. However, B-type ECM clauses display agreement; therefore, it means that such clauses bear full $\mathrm{C}^{0}$. Even though it bears a full $\mathrm{C}^{0}$, it is an interesting fact that the subject of this domain can be licensed by the verb of the matrix clause. On the other hand, when we have a closer inspection into the structure of root clauses, we see that the subject cannot be licensed by the matrix verb. The only difference between these two domains is that the latter bears a full $\mathrm{T}^{0}$ whereas the former does not. Here, one can easily point out the fact that it is $\mathrm{T}^{0}$ what determines the phase hood of these domains. Hence, we conclude that $\mathrm{T}^{0}$ is the key element that determines the opacity of the above-mentioned domains. This result clearly suggests that it is $\mathrm{T}^{0}$ what is missing in such ECM clauses. This finding is along the same line with Chomsky $(2000,2001)$ and Pesetsky \& Torrego (2007).

\section{Further Evidence: A Note on Raising Constructions}

What we have discussed so far is that $\mathrm{T}^{0}$ is defective in ECM clauses, and that it is $\mathrm{T}^{0}$ with full features which determine the phase hood of a given domain. Now, we are going to discuss an observation by George \& Kornfilt (1981) on raising constructions. George \& Kornfilt (1981) deny the tense-based notion of finiteness. On the basis of Turkish data, they redefine finiteness as the presence of (subject) agreement. They do this by showing that, in Turkish, it is the presence of agreement, rather than tense, which induces the effects associated with tensed clauses in English:

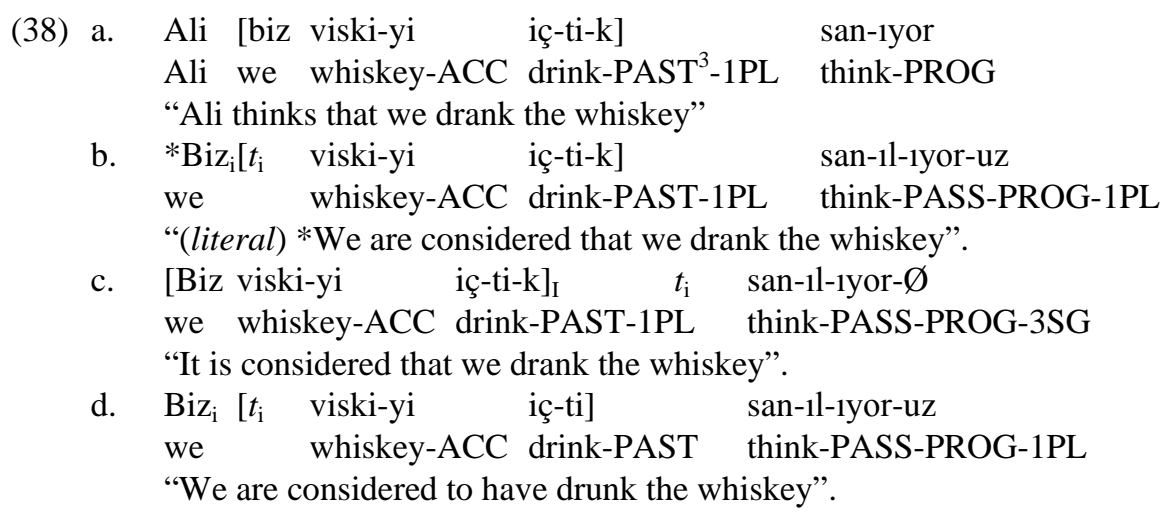

Focusing on (38d), we can maintain the idea that it is solely agreement which yields the effects associated ${ }^{3}$ We employed the original gloss provided by George and Kornfilt (1981). We do not share the same idea that $\{-\mathrm{DI}\}$ is a real past tense morpheme as already discussed in previous sections. 
with tensed clauses in English. Therefore, it is natural that the subject of the embedded clause in (38d) raises to matrix clause to license its case, since it is defective domain. The asymmetry between (38b) and (38c) bears out this observation in that in (38b) the raising of the embedded subject is not allowed whereas the raising of the whole clause is allowed in (38c). When we have a closer inspection into this data, it turns out to be deceptive. These statements do indeed lack tense marking, as put forward by George \& Kornfilt (1981):

(39) $* \operatorname{Biz}_{\mathrm{i}}\left[t_{\mathrm{i}}\right.$ viski-yi iç-iyor-du $] \quad$ san-1l-1yor-uz we whiskey-ACC drink-PROG-PAST think-PASS-PROG-1PL "(literal) *We are considered that we were drinking the whiskey".

If George \& Kornfilt (1981) were true, then the statement in (39) would also be rendered as grammatical since the embedded subject has already raised to matrix clause and licensed its case. The ungrammaticality of the clause suggests that the data that George \& Kornfilt (1981) provided lack real tense marking. Rather, they seem to bear the perfective aspectual marking. What is more, (38b) does not sound ungrammatical. It requires further analysis, which is beyond the scope of this study.

The above-mentioned argument is clearly borne out by the following raising constructions. It seems that tense feature is the key element that allows raising. That is, if there is no tense, then the raising is permitted:

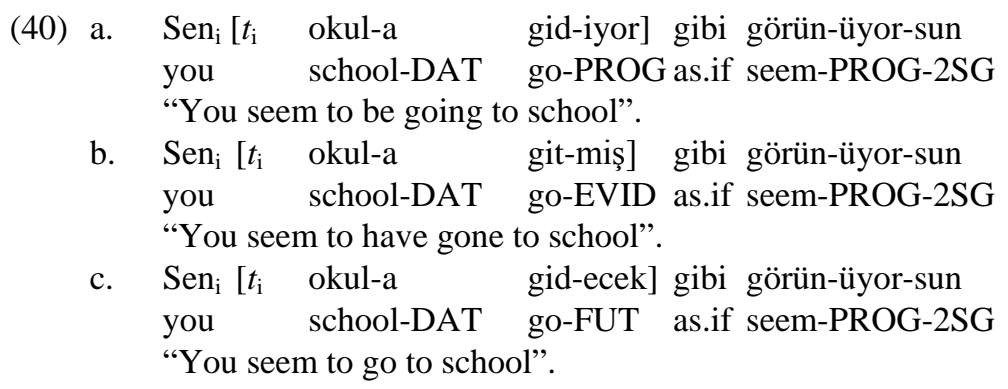

Neither of the statements provided in (40a-b-c) includes any tense marking. That is, $\mathrm{T}^{0}$ of the statements is defective which allows the subject to escape from the embedded clause and license its case in the matrix clause. This case is also true for embedded clauses with nominal clauses:

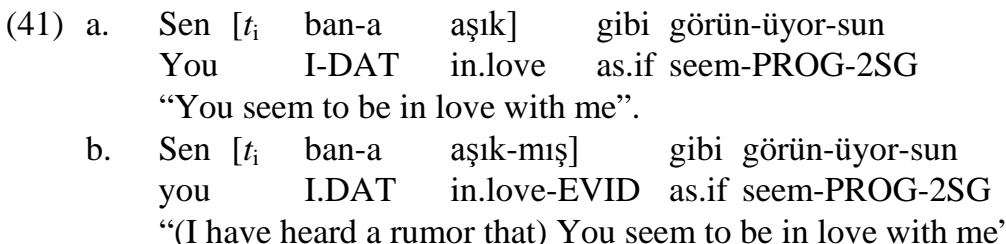

What is also the same case here as (40) is that we see an aspectual marking on the nominal predicate of the embedded clause in (41b). Therefore, we can see a raising construction from embedded clause to matrix clause. The main argument here is that this raising is allowed if and only if there is not tense marking on the verb of the embedded clause:

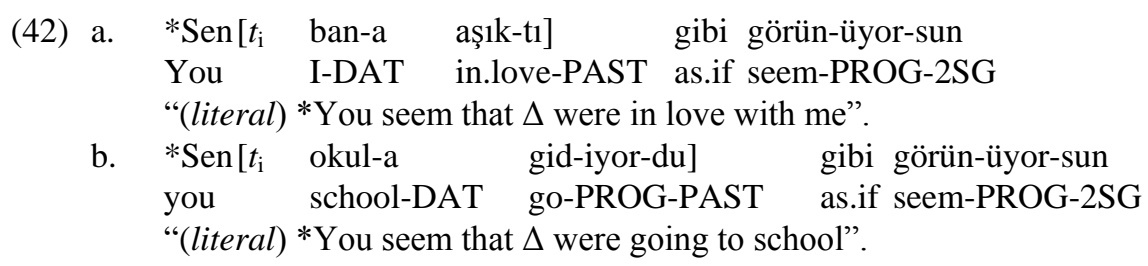

The difference between (40-41) and (42) is that the latter bears a $\mathrm{T}^{0}$ in the embedded clause; thus, a tense marking on the verb. The raising of the embedded subject to the matrix clause resulted in ungrammaticality, 
which bears out the assumption that $\mathrm{T}^{0}$ is the determining factor in such movement-like operations as raising, since it forms an opaque domain when it is not defective. In brief, we can conclude that, unlike George \& Kornfilt (1981), the finiteness is based on tense.

\section{Conclusion and Discussion}

In this study, we have discussed what the main missing feature in ECM clauses is with reference to Turkish ECM clauses. First, we began with a description of ECM clauses as dealt with in the literature. We have seen that the defectivity is bound to two heads: $\mathrm{C}^{0}$ and $\mathrm{T}^{0}$. However, we have come up with a triggering question for those cases in which there is a full $\mathrm{C}^{0}$, yet the clause is still defective. Then, we have evidenced that the domains are truly defective. The empirical proofs employed were long distance scrambling data, binding, and the licensing of negative polarity items. The following analysis section has revealed that the defectivity can also be accounted for on the basis of the $\mathrm{T}^{0}$ as well as $\mathrm{C}^{0}$. Last, we referred to the work by George \& Kornfilt (1981) in that the raising constructions can also be explained under the analysis we put forth in this study. To say, tense feature is the determining feature that decides on the opacity of a given domain.

Let us return to the main research questions stated in the very beginning of this study. The first question is as to whether it is possible that the phase is defect, even though the phase head is $\varphi$-complete. To answer this question, we return to the discussion that we maintained in the evidence section. We have seen that long distance scrambling (see (18)) as well as binding (see (25)) is allowed into the embedded clauses in B-type clauses, which is assumingly supposed to bear a full phase head, i.e. $C^{0}$. Furthermore, NPIs can also be licensed distantly in B-type ECM clauses (see (30)). These data clearly reveals that even though the phase head is $\varphi$-complete, it is possible that the phase can come out as a defective domain.

Now, let us turn our attention to the second research question of this study, which is as to whether all Core Functional Categories (CFCs), namely $v^{0}, \mathrm{~T}^{0}$ and $\mathrm{C}^{0}$, come into defective and complete versions. To answer this question we return to the distinction put forward by Richards (2007) given in (3) and repeated here:

$(2 \forall)[+[+/-$ defective $]]: \mathrm{C}^{0}, v^{0}$

[- [+/- defective] $]: \mathrm{T}^{0}$

Richards argued that the only CFCs that come into defective and complete versions are $\mathrm{C}^{0}$ and $v^{0}$. He resisted the idea that $\mathrm{T}^{0}$ also has a defective counterpart. However, we have seen that tense is a key factor determining the opacity of a given domain. Unless there is tense marking in a domain, that domain is transparent. We have evidenced this observation with A-type and B-type ECM clauses with reference to long distance scrambling, binding, and NPI data. Therefore, if we are to reshape the argument of Richards (2007), we get a picture along the same line with Chomsky $(2000,2001)$ and Pesetsky \& Torrego (2007) as follows:

(43) $[+[+/-$ defective $]]: \mathrm{C}^{0}, v^{0}, \mathrm{~T}^{0}$

Further studies can carry out processing tests to find out which side is empirically relevant. In addition, these arguments can also be tested on the basis of $v^{0}$.

\section{References}

Aygen, G. (2002). Finiteness, Case and Clausal Architecture. Unpublished Ph.D Dissertation, Cambridge, MA: Harvard University.

Bošković, Ž. (1997). The Syntax of Non-Finite Complementation: An Economy Approach. Cambridge: MIT Press.

Chomsky, N. (1995). The Minimalist Program. Cambridge: MIT Press.

Chomsky, N. (2000). Minimalist Inquiries: The Framework. In R. Martin et al. (Eds.), Step by Step. Essays on Minimalist Syntax in Honor of Howard Lasnik (pp. 89-155). Cambridge, MA: MIT Press.

Chomsky, N. (2001). Derivation by Phase. In M. Kenstowicz (Ed.), Ken Hale: A Life in Language (pp. 1-52). Cambridge, MA: MIT Press.

Chomsky, N. (2005). On Phases. Ms., MIT.

Dayal, V. S. (1994). Binding Facts in Hindi and the Scrambling Phenomenon. In M. Butt, T. Holloway King, \& G. Ramchand (Eds.), Theoretical Perspectives on Word Order in South Asian Languages (pp. 237-261). Stanford: CSLI Publica- 
tions.

Erguvanl1-Taylan, E. (1996). The Parameter of Aspect in Turkish. Modern Studies in Turkish. In A Konrot (Ed.), Proceedings of the 6th International Conference on Turkish Linguistics, 12-14 August 1992 (pp. 153-168). Eskişehir: Anadolu University.

Gallego, A. (2007). Phase Theory and Parametric Variation. PhD Dissertation in Cognitive Science and Language, Barcelona: Universitat Autònoma de Barcelona.

Gallego, A. J. (2009). Defective C-T in Romance. Probus, 21, 163-216. http://dx.doi.org/10.1515/prbs.2009.006

George, L., \& Kornfilt, J. (1981). Finiteness and Boundedness. In F. H. Turkish (Ed.), Binding and Filtering (pp. 105-128). London: Croomhellm Ltd.

Göksel, A. \& Kerslake, C. (2005). Turkish: A Comprehensive Grammar. New York: Routledge. http://dx.doi.org/10.4324/9780203340769

Herburger, E. (2001). The Negative Concord Puzzle Revisited. Natural Language Semantics, 9, 289-333. http://dx.doi.org/10.1023/A:1014205526722

Kelepir, M. (2001). Topics in Turkish Syntax: Clausal Structure and Scope. Unpublished PhD Dissertation, Cambridge, MA: Massachusetts Institute of Technology.

Knecht, L. (1985). Subject and Object in Turkish. Unpublished PhD Dissertation, Boston, MA: MIT.

Kornfilt, J. (1977). A Note on Subject Raising. Linguistic Inquiry, 8, 736-742.

Kural, M. (1993). V-to(-I-to)-C in Turkish. In F. Beghelli, \& M. Kural (Eds.), UCLA Occasional Papers in Linguistics (Vol. 11, pp. 1-37). Los Angeles, CA: UCLA Department of Linguistics.

Lee-Schoenfeld, V. (2004). Binding by Phase: (Non-)Complementarity in German. Journal of Germanic Linguistics, 16, 111-171. http://dx.doi.org/10.1017/S1470542704000376

Miyagawa, S. (1997). Against Optional Scrambling. Linguistic Inquiry, 28, 1-25.

Müller, G., \& Sternefeld, W. (1994). Scrambling as A-Bar Movemen. In N. Corver, \& H. van Riemsdijk (Eds.), Studies on Scrambling (pp. 331-386). Berlin: Mouton de Gruyter. http://dx.doi.org/10.1515/9783110857214.331

Pesetsky, D., \& Torrego, E. (2007). The Syntax of Valuation and the Interpretability of Features. In S. Karimi, V. Samiian, \& W. K. Wilkins (Eds.), Phrasal and Clausal Architecture (pp. 262-294). Amsterdam: John Benjamins. http://dx.doi.org/10.1075/la.101.14pes

Pullum, G. (1975). On a Non-Argument for the Cycle in Turkish. Linguistic Inquiry, 6, 494-501.

Richards, M. (2007). On Phases, Phase Heads, and Functional Categories. Nanzan Linguistics, 1, 105-127.

Rosenbaum, P. S. (1967). The Grammar of English Predicate Complement Constructions. Cambridge, MA: MIT Press.

Şener, S. (2008). Non-Canonical Case Licensing Is Canonical: Accusative Subjects of CPs in Turkish. Stowers, CT: University of Connecticut. http://ling.auf.net/lingbuzz/000759

Uzun, N. E. (1998). Türkçede görünüş/kip/zaman üçlüsü. Dil Dergisi, 68, 5-22.

Vikner, S. (1994). Scandinavian Object Shift and West Germanic Scrambling. In N. Cover, \& H. van Riemsdijk (Eds.), Studies on Scrambling (pp. 487-518). Berlin: Mouton de Gruyter. http://dx.doi.org/10.1515/9783110857214.487

Yavaş, F. (1980). On the Meaning of the Tense and Aspect Markers in Turkish. Unpublished PhD Dissertation, Stowers, CT: University of Connecticut.

Zidani-Eroğlu, L. (1997). Exceptionally Case-Marked NPs as Matrix Objects. Linguistic Inquiry, 28, 219-230. 


\section{Submit or recommend next manuscript to SCIRP and we will provide best service for you:}

Accepting pre-submission inquiries through Email, Facebook, LinkedIn, Twitter, etc.

A wide selection of journals (inclusive of 9 subjects, more than 200 journals)

Providing 24-hour high-quality service

User-friendly online submission system

Fair and swift peer-review system

Efficient typesetting and proofreading procedure

Display of the result of downloads and visits, as well as the number of cited articles

Maximum dissemination of your research work

Submit your manuscript at: http://papersubmission.scirp.org/ 